Report No. WR-B-97-03
U.S. Department of Fnergy

Office of Inspector General

Report on

\title{
Audit of Groundwater Monitoring at Hanford
}

ASTRIBUTION OF THIS DOCUMENT IS UNLIMTTED

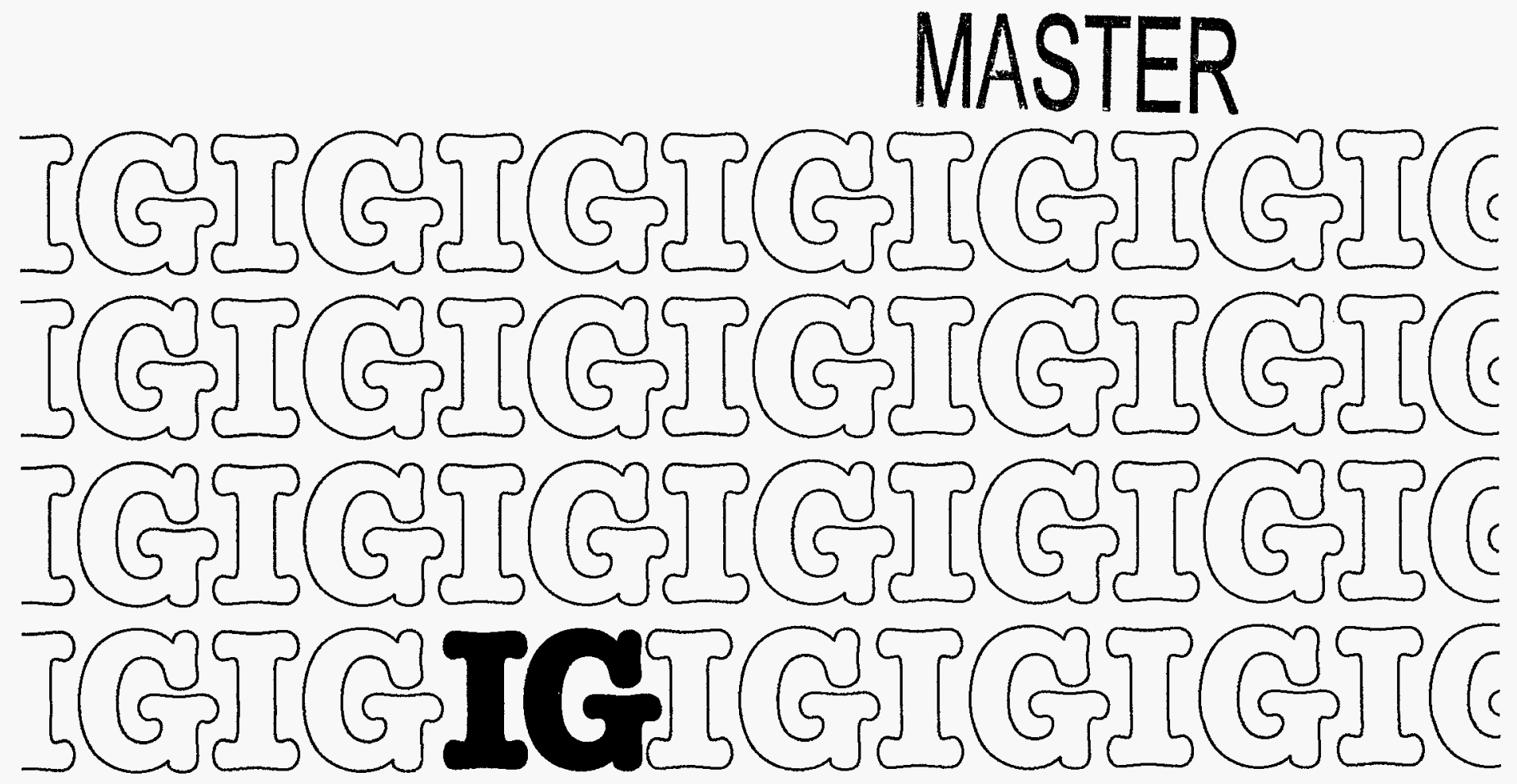


The Office of Inspector General wants to make the distribution of its reports as customer friendly and cost effective as possible. Therefore, this report will be available electronically through the Internet five to seven days after publication at the following alternative addresses:

\author{
Department of Energy Headquarters Gopher \\ gopher.hr.doe.gov \\ Department of Energy Headquarters Anonymous FTP \\ vm1.hqadmin.doe.gov \\ U.S. Department of Energy Human Resources and Administration \\ Home Page \\ http://www.hr.doe.gov/ig
}

Your comments would be appreciated and can be provided on the Customer Response Form attached to the report.

This report can be obtained from the

U.S. Department of Energy

Office of Scientific and Technical Information

P.O. Box 62

Oak Ridge, Tennessee 37831 
U.S. DEPARTMENT OF ENERGY

OFFICE OF INSPECTOR GENERAL

AUDIT OF GROUNDWATER MONITORING AT HANFORD

Report Number: WR-B-97-01

Date of Issue: November 15, 1996
Western Regional Audit Office

Albuquerque, New Mexico 87185 


\section{DISCLAIMER}

Portions of this document may be illegible in electronic image products. Images are produced from the best available original document. 


\section{TABLE OF CONTENTS}

Page

SUMMARY ................................................................. 1

PART I - APPROACH AND OVERVIEW........................................ 2

Introduction................................................................. 2

Scope and Methodology ................................................. 2

Background....................................................................... 3

Observations and Conclusions.............................................. 3

PART II -FINDING AND RECOMMENDATIONS.............................. 4

Hanford Site Groundwater Monitoring...................................... 4

PART III -MANAGEMENT AND AUDITOR COMMENTS ........................ 8 


\section{U.S. DEPARTMENT OF ENERGY \\ OFFICE OF INSPECTOR GENERAL \\ OFFICE OF AUDIT SERVICES \\ WESTERN REGIONAL AUDIT OFFICE}

\section{AUDIT OF GROUNDWATER MONITORING AT HANFORD}

Audit Report Number: WR-B-97-03

Novemer 15, 1996

\section{SUMMARY}

The Department of Energy (Department), Richland Operations Office (Richland) is responsible for ensuring that its contractors' tasks are mission oriented and are completed at the least cost to the Department. The objective of this audit was to determine whether Richland was effectively managing its groundwater monitoring activities so that unnecessary duplication would not occur.

The audit showed that while Richland's groundwater monitoring program was mission essential, it was not performed at the least cost to the Department. Work performed by the three principle contractors overlapped, resulting in duplicative groundwater monitoring activities. Because of duplicative efforts, the Department spent at least $\$ 700,000$ in Fiscal Year 1995 and 1996 more than it should have and could save at least $\$ 500,000$ annually by implementing action to ensure coordination of contractor's work for Hanford's groundwater monitoring.

We recommended that the Manager, Richland, give mission authority to the groundwater monitoring group to develop a management strategy to coordinate Hanford's Site contractors' groundwater monitoring activities.

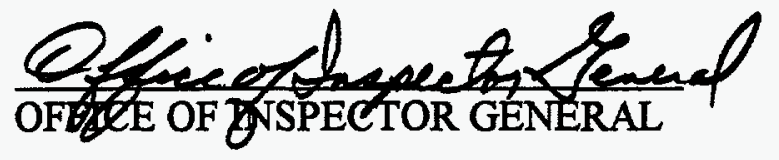




\section{$\underline{\text { PART I }}$}

\section{APPROACH AND OVERVIEW}

\section{INTRODUCTION}

The Resource Conservation and Recovery Act of 1976 (RCRA) and the Comprehensive Environmental Response, Compensation, and Liability Act of 1980 (CERCLA)--as well as DOE Order 5400.1--govern how the Richland Operations Office (Richland) is to perform its cleanup activities. To ensure efficient compliance with certain aspects of these regulatory requirements, Richland formed a management group to coordinate the groundwater monitoring activities of its contractors. The objective of this audit was to determine whether Richland was effectively managing its groundwater monitoring activities so that unnecessary duplication would not occur.

\section{SCOPE AND METHODOLOGY}

The audit was performed from November 28, 1995 through June 30, 1996, at Richland and its prime contractors: Westinghouse Hanford Company (Westinghouse); Battelle-Pacific Northwest National Laboratory (Battelle); and Bechtel Hanford Incorporated (Bechtel), as well as at the Hanford Site. We accomplished the audit objective by:

- reviewing laws and regulations;

- interviewing Department and contractor personnel;

- examining procurement and accounting procedures;

- reviewing plans, budgets, and actual expenditures;

- reviewing utilization of Department drilling equipment;

- observing well drilling activities;

- comparing drilling costs to other Department sites;

- analyzing groundwater monitoring activities; and,

- reviewing and comparing groundwater reports.

The audit, conducted in accordance with generally accepted Government Auditing Standards for economy and efficiency audits, included tests of internal controls, laws, and regulations to the extent necessary to satisfy the audit objective. We did not extensively rely on computer-generated data; therefore, we did not fully examine the reliability of that data. Because the audit was limited, it would not necessarily have disclosed all internal control deficiencies that may have existed. 
An exit conference was held with the Director, Restoration Projects Division, the staff for the groundwater monitoring management group and a representative from the Contract Finance and Review Division on October 23, 1996.

\section{BACKGROUND}

With the closing of Hanford's production reactors, the Site's primary focus has changed from producing plutonium to cleanup. A part of the cleanup is the monitoring of waste source areas such as tank farms, ponds, and landfills to determine if contaminants have been released into the groundwater. If contaminants have been released, monitoring is used to assess and document the extent and rate of contaminant movement so that the appropriate remedial actions can be implemented.

The Department funds the groundwater monitoring through Hanford's Waste Management and Environmental Restoration programs. In Fiscal Year 1996, Richland provided each contractor the funds to perform groundwater monitoring, remediation, and surveillance activities such as well drilling and maintenance, groundwater sampling and analysis, and reporting. Richland divided \$48 million among three contractors. Westinghouse received \$15.6 million to perform RCRA groundwater monitoring; of which $\$ 8.9$ million was for groundwater monitoring and supporting activities; Bechtel received \$30 million to perform CERCLA remediation work; of which about $\$ 700,000$ was for groundwater monitoring; and Battelle received \$2.4 million to perform sitewide groundwater surveillance.

\section{OBSERVATIONS AND CONCLUSIONS}

The audit showed that one aspect of Hanford's groundwater monitoring--specifically, the drilling program--has improved. In an effort to more effectively manage site cleanup and control costs, Richland contracted with an environmental restoration contractor in 1993 to conduct restoration of the Hanford Site. The new contractor competitively awarded drilling subcontracts for CERCLA well drilling. This procurement established fixed unit costs for each well drilled and reduced the number of personnel required for drilling. Richland also cut costs by employing alternative drilling technologies. In addition, Richland negotiated with Tri-Party regulators and reduced the number of new RCRA wells required from 50 per year to "up to 50" per year (no wells were installed in FY 1995 and only one was installed in FY 1996). These actions and others have made Hanford's drilling costs reasonable and comparable with other Department sites.

While well drilling activities have improved, the audit detected problems with Richland's overall coordination of groundwater monitoring, as described in Part II. Despite efforts to address known problems, the Department still needs improvement to its management plan to better coordinate current monitoring tasks and avoid future duplication. The necessity for such improvements, however, is not limited to Hanford. A recent OIG report, Audit of Groundwater Remediation Plans at the Savannah River Site (ER-B-96-02), for example, concluded that management plans for groundwater remediation at this site also needed to be improved. 
PART II

FINDING AND RECOMMENDATIONS

Hanford Groundwater Monitoring

\section{FINDING}

Richland is responsible for ensuring that its contractors' tasks are mission oriented and are completed at the least cost to the Department. The audit determined, however, that while Richland's groundwater monitoring program was mission essential, it was not performed at the least cost to the Department. Work performed by the three principle contractors overlapped, resulting in duplicative groundwater monitoring activities. Although Richland established a group to manage groundwater activities, it had not given the group a defined mission, nor had it provided function statements or job descriptions. Unless the group is given such official sanction, it can not ensure that groundwater monitoring activities are coordinated and not duplicative. Because of duplicative efforts, the Department spent about $\$ 700,000$ more than it should have for monitoring and could save over $\$ 500,000$ annually by implementing actions to ensure coordination of contractors' work for Hanford's groundwater monitoring.

\section{RECOMMENDATIONS}

We recommend that the Manager, Richland Operations Office, ensure that the groundwater monitoring program is effective and efficient. Specifically, we recommend that the Manager:

1. Establish a defined mission, provide function statements, and give job descriptions for the group formed to manage and coordinate the Hanford site groundwater monitoring activities.

2. Direct the groundwater monitoring group to develop a management strategy to coordinate Hanford contractors' groundwater monitoring activities.

\section{MANAGEMENT REACTION}

Management concurred with recommendation 1 and took action that was responsive to recommendation 2. Details of management's comments and our responses are included in Part III.

\section{DETAILS OF FINDING}

Richland is responsible for ensuring its contractors' work is mission oriented, complies with federal regulations, and is conducted at the least cost to the Department. As outlined in its 1994 "Hanford Strategic Plan," Richland was to integrate Hanford activities through established goals and management strategies. One such goal was to manage cleanup efficiently by applying 
management principles to achieve the desired end as quickly and cost effectively as possible. Another was to have an effective decisionmaking process that balanced quality, acceptance, and timeliness of the decision. Further, Richland sought to integrate all related contractor activities. Integration, in this sense, refers to optimize resources to achieve as many mission objectives as possible with the least duplication of effort.

\section{GROUNDWATER MONITORING ACTIVITIES}

The audit showed, however, that despite these goals, Westinghouse, Battelle, and Bechtel had not completely eliminated duplicated groundwater monitoring activities. The contractors duplicated each others' work in groundwater sampling and modeling analyses. Further, two of the contractors produced duplicative reports and maintained similar management positions.

\section{Sampling Analysis}

During 1995, Westinghouse and Battelle duplicated efforts by collecting water samples from the same wells within 30 days of each other. This occurred at 56 different wells during 1995. In February 1995, for example, Westinghouse visited well 199-K-27, took a water sample, and analyzed it for about 12 constituents, such as bromide, chloride, fluoride, and nitrate. One day later, Battelle visited the same well, also drew a water sample, and tested it for the exact same constituents. Officials at each contractor did not provide substantive or qualitative reasons for taking duplicative samples. If appropriate coordination had occurred, either contractor could have used the other's sample results. Instead, costs associated with visiting the 56 wells and analyzing the samples were paid twice.

This duplicative activity continued into 1996 as well. A review of monitoring activities for the first 6 months of 1996 showed that at least two of the Site's contractors visited the same wells 33 times within 30 days of each other. One example showed that Westinghouse duplicated its own efforts on at least four occasions by visiting the same wells several times within a few days for different projects. As in 1995, there was no substantive reason for doing so and coordinated efforts could have eliminated at least 33 samples and 33 sets of analyses. Had the contractors adequately planned, information could have been gathered for all contractors at once.

\section{Modeling Analysis}

Hanford contractors also duplicated each others' work in modeling. For example, Westinghouse, Battelle, and Bechtel each applied their own models of groundwater movement. In applying these models, the contractors duplicated groundwater analyses to predict such action as declining groundwater levels and the groundwater flow from an effluent disposal site. Additionally, two contractors, Westinghouse and Bechtel, each paid the same subcontractor on separate projects to develop forecasts of groundwater contamination migration using separate models. According to Richland officials, separate models were not necessary for qualitative or scientific reasons, but were the result of poor coordination. 
$\underline{\text { Reports }}$

Westinghouse and Battelle each published annual reports about Hanford Site groundwater to comply with environmental laws and a Department Order. The reports contained similar information, such as hydrogeology and radionuclide analyses. In addition, Battelle published a third report that had one chapter discussing groundwater monitoring sampling and analysis. Although the reports were published to satisfy statutory requirements, all such requirements could have been met with a single document. Instead, the Department paid each of the two contractors to produce separate reports. When questioned during the audit, current users of the reports agreed that the reports were duplicative and that all requirements could be satisfied with one combined report.

\section{Management Positions}

Because the audit identified several areas of potential consolidation, as discussed above, we also examined contractor management positions related to groundwater monitoring to determine whether further efficiencies were available. Two contractors, Westinghouse and Battelle, maintained organizations with overlapping responsibilities. For example, we noted that Westinghouse's Liquid Effluents Services performed many of the same functions as Battelle's Groundwater Surveillance Project. These two separate organizations used six personnel to manage the activities. We discussed these concerns with Westinghouse's Environmental Services Manager, who agreed with us that, given a more coordinated approach, only three full time equivalent management positions were need to effectively manage monitoring activities.

\section{COORDINATION OF GROUNDWATER MONITORING}

We were able to determine that duplicative activities of the Hanford Site contractors have been ongoing since at least 1988 . This resulted because Richland had not coordinated the contractors' groundwater monitoring activities. In October 1995, Richland formed a group with the mission to coordinate such activities. Since that time, this group has made efforts to consolidate both the groundwater monitoring and reporting. Although we believe the formation of the group is a positive action, the group, as of the time of our audit, had neither received an official charter nor position descriptions. We believe that such official authority is needed to ensure success for the group. In addition, although the group had started some actions, it had not, as of June 30,1996 , developed an official strategy to address overlapping groundwater monitoring activities.

\section{COSTS OF DUPLICATIVE EFFORTS}

The costs associated with duplicative groundwater monitoring activities are significant. By implementing the report recommendations to better control and coordinate monitoring, Richland has the opportunity to reduce unnecessary costs by about $\$ 500,000$ annually. For example, although the exact amount could not be determine, Richland could at least save $\$ 103,600$ by ensuring duplicative groundwater sampling is reduced. Also, by combining 
groundwater reporting, savings of $\$ 164,000$ can be achieved. Finally, by consolidating groundwater monitoring management, Richland could reduce personnel costs by about $\$ 230,000$.

In addition to the estimated savings, Richland unnecessarily spent almost $\$ 100,000$ $(\$ 26,000+\$ 72,000)$ for three Hanford Site contractors to perform similar groundwater analysis. For example, Westinghouse, Battelle, and Bechtel each predicted impacts of declining Hanford Site groundwater levels. In Fiscal Year 1994, Battelle completed an analysis for about $\$ 50,000$ that predicted the groundwater levels for the next 15 years. Later that same fiscal year, Westinghouse completed a similar analysis for $\$ 26,000$. Finally, in Fiscal Year 1996 Bechtel again made an analysis predicting groundwater levels for $\$ 72,000$. Another example showed that in Fiscal Year 1996, Westinghouse and Bechtel each hired the same subcontractor, for $\$ 475,000$ and $\$ 400,000$, respectively, to perform groundwater modeling for the Hanford Site Remedial Action Environmental Impact Statement and the Environmental Impact Statement for the Tank Waste Remediation System. According to Richland officials, had there been a coordinated approach, the subcontract could have used the same model for both statements, thereby, reducing overall costs. 
PART III

\section{MANAGEMENT AND AUDITOR COMMENTS}

The Manager, Richland Operations Office, concurred with one recommendation, took action on the other, and provided additional comments as detailed below.

\section{RECOMMENDATIONS}

Management Comments. Management concurred with recommendation 1, agreeing to establish a defined mission, provide function statements, and give job descriptions for the groundwater monitoring group.

Auditor Comments. Management's comments are responsive; however, Richland should provide an estimated completion date for this action.

Management Comments. Richland did not concur with recommendation 2, to develop a management strategy to coordinate Hanford contractors' groundwater monitoring activities. However, on September 5, 1996, one of Richland's contracting officers issued a letter to the Hanford contractors that stated Richland has moved to a single "groundwater project" for Hanford and away from separate and distinct groundwater "programs" operated by three contractors. The letter defined the roles and responsibilities each contractor was to follow in the future to avoid redundancies and inefficiencies in the groundwater programs.

Auditor Comments. Even though Richland did not concur with the recommendation, if it follows its own directions it will achieve the results that we sought. Therefore, we have treated management's actions as a concurrence.

\section{COST SAVINGS}

Management Comments. Management indicated that the benefit of combining groundwater monitoring reports was overstated. In fact, management estimated that the cost to prepare a single report was $\$ 274,000$, the same amount currently spent to produce two reports.

Auditor Comments. The Office of Inspector General estimate of savings includes annual report preparation costs for two contractors to procure printing, paper, graphics, reviewers, coordination, word processing and some quality control. Data provided to us by management showed that the cost for one contractor to prepare one report was about $\$ 110,000$. Potential savings, therefore, of about $\$ 164,000(\$ 274,000-\$ 110,000)$ should be available. 
Report No. WR-B-97-03

\section{CUSTOMER RESPONSE FORM}

The Office of Inspector General has a continuing interest in improving the usefulness of its products. We wish to make our reports as responsive as possible to our customers' requirements, and therefore ask that you consider sharing your thoughts with us. On the back of this form, you may suggest improvements to enhance the effectiveness of future reports. Please include answers to the following questions if they are applicable to you:

1. What additional background information about the selection, scheduling, scope, or procedures of the audit or inspection would have been helpful to the reader in understanding this report?

2. What additional information related to findings and recommendations could have been included in this report to assist management in implementing corrective actions?

3. What format, stylistic, or organizational changes might have made this report's overall message more clear to the reader?

4. What additional actions could the Office of Inspector General have taken on the issues discussed in this report which would have been helpful?

Please include your name and telephone number so that we may contact you should we have any questions about your comments.

Name Date

Telephone Organization

When you have completed this form, you may telefax it to the Office of Inspector General at (202) 586-0948, or you may mail it to:

Office of Inspector General (IG-1)

U.S. Department of Energy

Washington, D.C. 20585

ATTN: Customer Relations

If you wish to discuss this report or your comments with a staff member of the Office of Inspector General, please contact Wilma Slaughter at (202) 586-1924. 